\title{
Gabriella Sandström Kristallklara e-tjänster - arbetet bakom kulisserna
}

Språkrådet $i$ Sverige delar varje år ut Klarspråkskristallen till en myndighet eller annan offentlig verksamhet som arbetat framgångsrikt med klarspråk. År 2016 var temat för priset klarspråk i e-tjänster. Jag har undersökt arbetsprocessen bakom tre av de nominerade bidragen. Trots att de skiljer sig åt när det gäller typ av tjänst, målgrupp och syfte har de mycket gemensamt. Exempelvis har alla e-tjänsterna utvecklats utifrån tidigare erfarenheter av och kunskaper om vad användarna tycker är svårt. Här följer några av de gemensamma framgångsfaktorerna:

- noggrann analys av användarnas behov utifrån exempelvis användartester och intervjuer

- tydliga effektmål

- nära samarbete mellan olika kompetenser

- enhetlig terminologi

- kontinuerliga utvärderingar och revideringar under projektets gång.

\section{Erfarenheter från tre framgångsrika klarspråksprojekt}

Vad är det som gör att vissa klarspråksprojekt lyckas särskilt bra? Vilka är framgångsfaktorerna? I den här artikeln vill jag lyfta fram erfarenheterna från tre utvecklingsprojekt i offentlig verksamhet som Språkrådet har fătt ta del av genom nomineringar till priset Klarspråkskristallen år 2016. Projekten gäller utveckling av så kallade e-tjänster - tjänster på digitala plattformar som riktar sig till medborgare eller företag.

Artikeln kommer främst att fokusera på arbetsformer som visat sig framgångsrika vid utvecklingen av begripliga och användbara e-tjänster och inte så mycket på 
e-tjänsterna i sig. Syftet är att sprida kunskap om framgångsrika arbetsformer och lyfta fram goda exempel - inte bara vid utveckling av e-tjänster utan i klarspråksprojekt i allmänhet.

\section{Om priset Klarspråkskristallen}

Klarspråkskristallen är ett pris för klart och begripligt språk i offentlig verksamhet. Det har delats ut till myndigheter, kommuner och landsting sedan 1998 och är en belöning för goda resultat i klarspråksarbetet. Syftet är också att uppmuntra till fortsatta insatser och att inspirera andra. Priset administreras av Språkrådet, men vinnaren utses av en utomstående jury.

Vartannat år har priset ett allmänt tema, föredömligt klarspråksarbete, och vartannat år har det ett särskilt tema. År 2016 var temat klarspråk i e-tjänster.

\section{De nominerade e-tjänsterna}

De tre nomineringar till Klarspråkskristallen som jag har valt att redogöra för är insända av två centrala myndigheter och en kommun: Bolagsverket, Socialstyrelsen och Sundsvalls kommun. (För enkelhetens skull använder jag myndigheter som en samlande benämning i artikeln.) Jag har valt just dessa nomineringar för att e-tjänsterna, trots stora olikheter när det gäller målgrupper och inriktning, har mycket gemensamt vad gäller arbetsprocesserna bakom. Jag har även sammanställt ett antal faktorer som myndigheterna själva beskrivit som framgångsrika.

Uppgifterna och citaten i artikeln är hämtade ur respektive myndighets nominering, om inget annat anges.

\section{Bolagsverket - registrera företag}

Bolagsverket är en statlig myndighet som bland annat granskar och registrerar företag och föreningar. Myndigheten har i uppdrag att underlätta för Sveriges företagare, exempelvis vid start av nytt företag, och driver webbplatsen verksamt.se i samarbete med tre andra myndigheter, bland andra Skatteverket.

Bild 1 visar ett exempel från den nominerade e-tjänsten Registrera företag och skydda företagsnamn på verksamt.se. I den här skärmbilden ska användaren ange datum när företaget bildades samt på vilken ort. (Registrera företag och skydda företagsnamn 2017) 


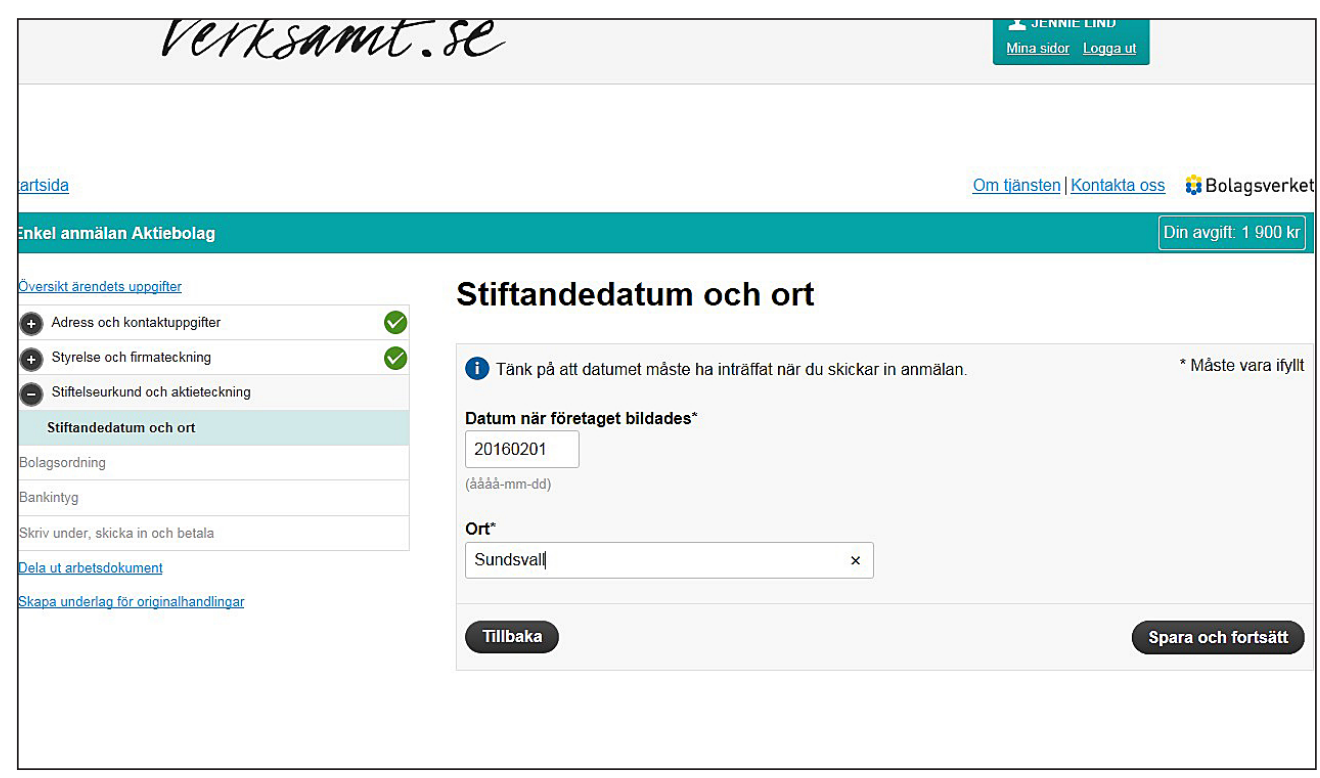

Bild 1: Bolagsverkets e-tjänst för att registrera företag, i det här fallet aktiebolag

\section{Socialstyrelsen - ansöka om yrkeslegitimation för arbete i hälso- och sjukvården}

Socialstyrelsen är en statlig myndighet med verksamhet som rör socialtjänst och hälso- och sjukvård. Verksamheten riktar sig främst till personal och beslutsfattare inom dessa områden, mer sällan direkt till medborgare. På myndigheten fattar man bland annat beslut om legitimationer för 21 yrkesgrupper, exempelvis läkare, apotekare och sjuksköterskor.

På Socialstyrelsens webbplats finns information för personer som ansöker om svensk legitimation för att få arbeta i hälso- och sjukvården i Sverige. Det är olika ansökningsprocesser och varierande krav beroende på yrke och vilket land den sökande är utbildad i. Processen är komplex och pågår ofta under en längre tid. Informationen presenteras stegvis, och den sökande ska bland annat skicka in intyg från utbildningar, kurser och prov samt andra bilagor.

Bild 2 visar startbilden för e-tjänsten, där användarna länkas till olika undersidor beroende på om de är utbildade i Sverige, inom Europeiska unionen (EU) eller Europeiska ekonomiska samarbetsområdet (EES) eller utom EU och EES-området. (Ansök om legitimation 2016) 


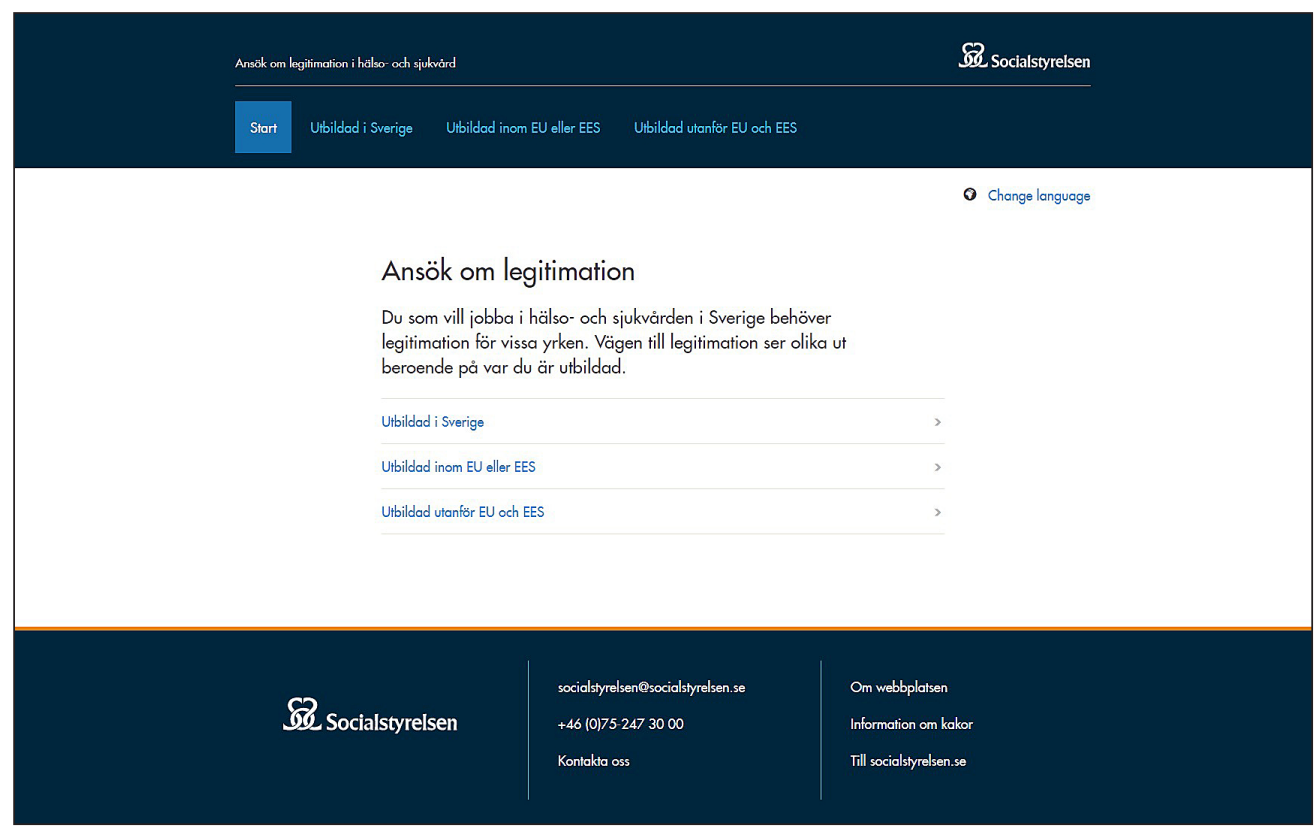

Bild 2: Socialstyrelsens e-tjänst för att ansöka om svensk yrkeslegitimation

\section{Sundsvalls kommun - ansöka om skolskjuts för elever med specialbehov}

Sundsvalls kommun ligger i Västernorrlands län och har cirka 100000 invånare. Kommunen ingår i ett nätverk tillsammans med fem andra kommuner i länet som gemensamt utvecklar e-tjänster för medborgarna. De utvecklar e-tjänsterna i öppen källkod som de delar med sig av.

Skolskjuts är en e-tjänst för föräldrar till barn med specialbehov som behöver köras till skolan med taxi eller buss. I dessa fall måste en handläggare på kommunen först utreda ärendet innan skolskjuts kan beviljas.

Bild 3 visar startbilden för e-tjänsten, där föräldern får ange orsaken till att barnet behöver skolskjuts. Startbilden ger även en tydlig översikt av vilka steg som ingår i ansökningsprocessen. (Ansökan om skolskjuts 2016) 


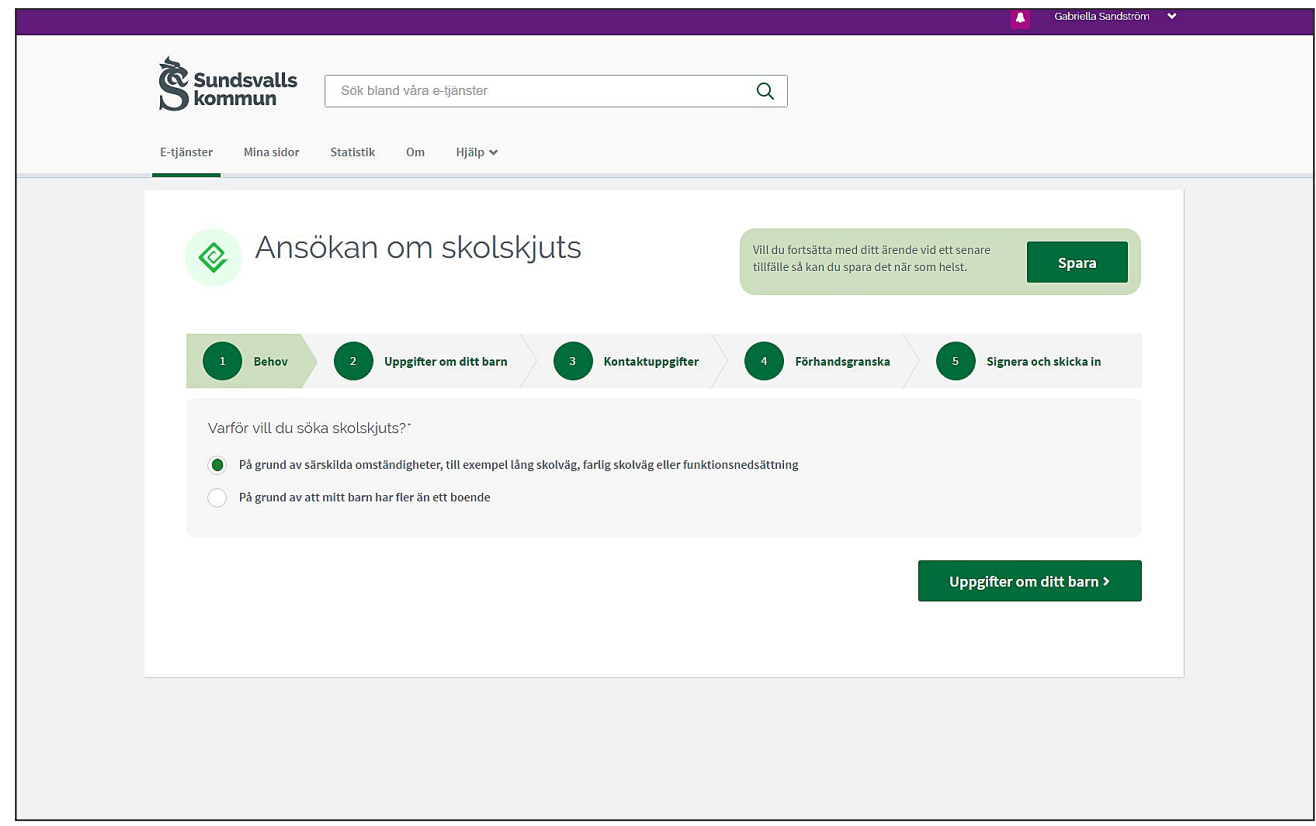

Bild 3: Sundsvalls kommuns e-tjänst för att ansöka om skolskjuts

\section{Utgångsläget - varför utveckla en e-tjänst?}

Utgångspunkten för samtliga tre myndigheter är att de haft blanketter, en äldre e-tjänst eller webbsidor som användarna på olika sätt haft svårigheter med.

Bolagsverkets tidigare e-tjänst för att registrera företag innehöll mycket information om lagar och regler. Det kom synpunkter från både kunder och medarbetare om att den upplevdes som svårförståelig och svåranvänd av kunderna. En stor andel av dem använde pappersblanketter i stället för e-tjänsten.

Socialstyrelsen behövde ta fram en ny e-tjänst för att underlätta den komplexa processen för dem som ansöker om yrkeslegitimation och därmed förkorta den långa handläggningstiden. Ansökningarna behövde ofta kompletteras, och det krävdes många kontakter mellan sökande och handläggare. Många av de sökande har ett annat modersmål än svenska, vilket innebär särskilda utmaningar för myndigheten att förklara och hjälpa dem att göra rätt. Texterna på den gamla webbplatsen var långa och dessutom skrivna utifrån myndighetens perspektiv. Man hade också en ineffektiv arbetsprocess där jurister och kommunikatörer inte arbetade tillsammans och där juridiska krav och klarspråkskrav ofta ställdes mot varandra. Myndigheten startade därför ett pilotprojekt för att prova både ny teknik och nya arbetsformer.

Sundsvalls kommun hade tidigare en blankett som var svår för föräldrarna att fylla i, och reglerna upplevdes som krångliga. Informationen som ska lämnas är ofta komplex, vilket ställer krav på enkelhet och tydlighet i instruktionerna. 


\section{Metoder för att ta reda på vad användarna av e-tjänsten behöver}

Myndigheterna beskriver olika sätt att ta reda på vilka behov användarna av e-tjänsten har. Ofta finns redan kunskap inom organisationen om vad användarna tycker är svårt, exempelvis hos personal i kundtjänsten eller upplysningstjänsten. Framför allt har handläggare av ärenden ofta stora kunskaper om vad som kan orsaka problem för användarna.

På Bolagsverket började man med att utvärdera användbarheten hos den tidigare e-tjänsten. En extern konsult anordnade träffar med företagare, som fick testa e-tjänsten i praktiken och efteråt intervjuades om det. De fick även svara på frågor om språket i e-tjänsten. De problem och lösningsförslag som identifierades under utvärderingen blev sedan underlag till ett användbarhetsprojekt. Samtidigt sammanställde och analyserade man de synpunkter på e-tjänsten som kommit in från kunder och personal.

På Socialstyrelsen gjorde man målgruppsanalyser och hade då stor nytta av de handläggare av legitimationsärenden som ingick i arbetsgruppen. Dessutom lyssnade man på telefonsamtal till upplysningstjänsten och gjorde intervjuer med Arbetsförmedlingens handläggare, som har stora erfarenheter av vad sökande brukar tycka är svårt.

I Sundsvalls kommun inleddes utvecklingsarbetet med att projektgruppen höll en

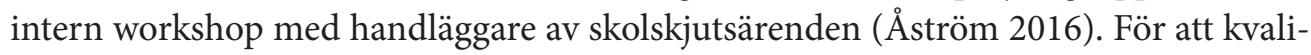
tetssäkra språket och undvika intern jargong fick föräldrar testläsa texter och ta ställning till om de var lätta att förstå och använda för att ansöka om skolskjuts.

\section{Personor - ett sätt att få en gemensam bild av användarnas behov}

På Socialstyrelsen tog man fram så kallade personor för att skapa en tydlig, gemensam bild av användarnas behov och förutsättningar. En persona i användbarhetssammanhang är en fiktiv karaktär som är framtagen för att representera en viss grupp av användare av exempelvis en webbplats. Den beskrivs i form av användarbeteenden, mål, färdigheter och attityder och kompletteras med några fiktiva personliga detaljer för att personan ska framstå som realistisk (Persona [user experience] 2016).

Socialstyrelsens tre personor representerar yrkena tandläkare, apotekare och läkare, och alla sökande har kommit olika långt $\mathrm{i}$ ansökningsprocessen. Utifrån analysen av de sökandes behov har man i projektet formulerat vad användarna behöver veta och göra i varje skede, deras förståelse för processen och deras kunskaper om hur svensk sjukvård fungerar. För varje persona har man även formulerat interna utmaningar och mål. (Socialstyrelsen 2016b) 

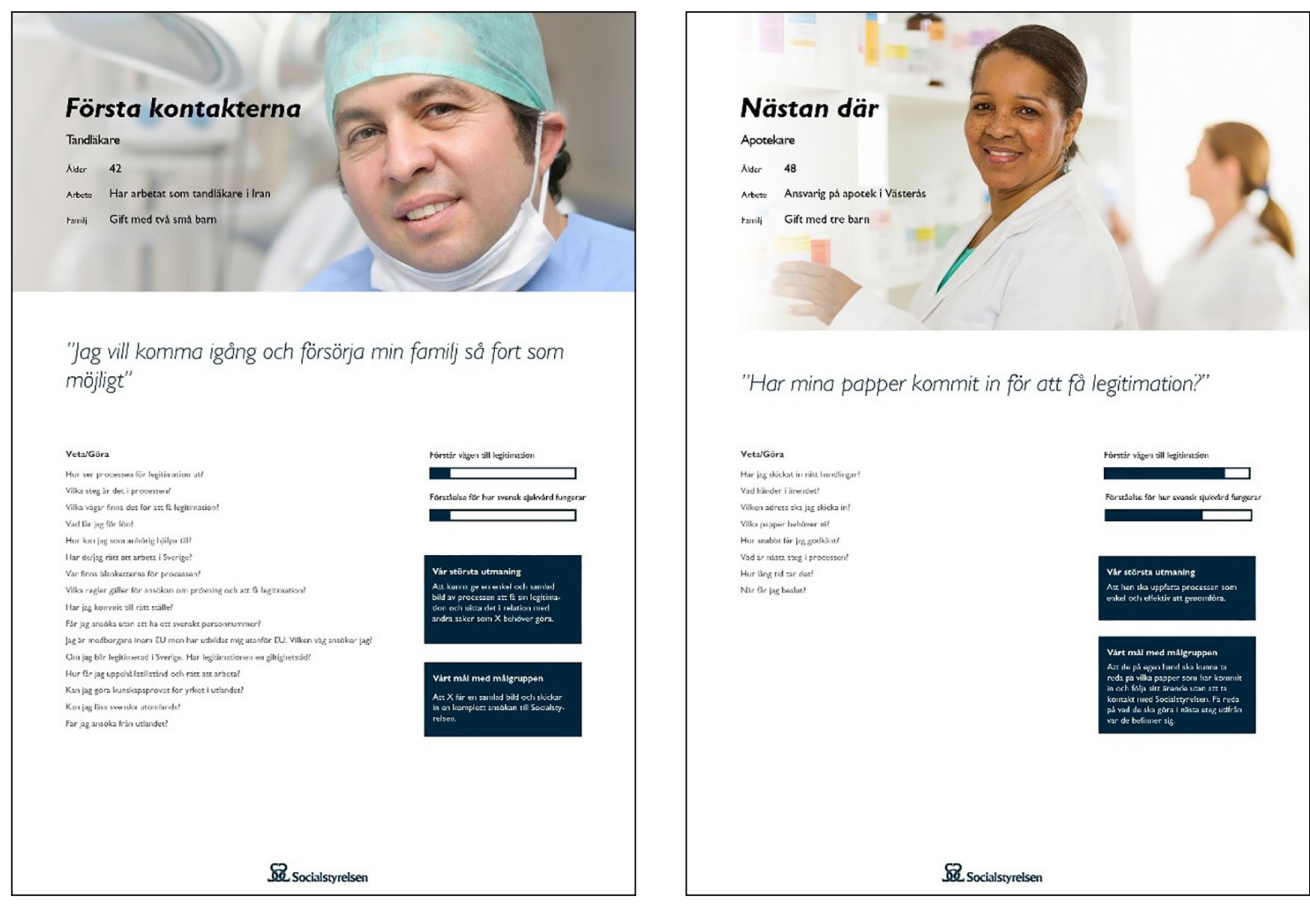

Bild 4: Socialstyrelsens personor för yrkena tandläkare och apotekare. (Socialstyrelsen 2016b)

\section{Sätta tydliga effektmål}

En av de framgångsfaktorer som myndigheterna beskrivit är tydliga effektmål, som beskriver vad man vill åstadkomma. Målen är viktiga för att man ska kunna utvärdera resultatet av arbetet och får gärna vara mätbara. Det kan exempelvis vara färre frågor till myndigheten, kortare väntetid eller ökad användning av e-tjänsten. (Hur det gick framgår av avsnittet "Förbättringar av e-tjänsterna och resultat av projekten".)

På Bolagsverket var målen att förbättra användarvänligheten och öka användningen av e-tjänsten. Ett delmål var att få ner textmängden i e-tjänsten och låta formulären vara så "rena" som möjligt. Exempelvis flyttades långa texter med juridisk information från själva formuläret till en flik som kan fällas ut av användaren.

På Socialstyrelsen lade man ned mycket tid i början av pilotprojektet på att fastställa gemensamma effektmål. Målet var att få in bättre ansökningar och färre frågor och kompletteringar, vilket i slutänden ska leda till kortare handläggningstid för ärendena.

I Sundsvalls kommun ville man, enligt nomineringen, ta fram "en enkel och begriplig tjänst som många medborgare kan ha nytta av i vardagen”. Ett annat av projektets mål var att arbetsmetoden skulle kunna användas igen. 


\section{Samarbete mellan olika kompetenser leder till ökad effektivitet och högre kvalitet}

Alla tre myndigheterna beskriver hur de satte ihop arbetsgrupper i utvecklingsprojekten så att flera yrken, roller och kompetenser fanns representerade. Förutom itutvecklare och användbarhetsexperter kopplade man in exempelvis jurister, handläggare, ämnesexperter, kundtjänstpersonal, kommunikatörer och språkvårdare.

Bolagsverket lyfter i sin nominering fram ökad effektivitet som ett resultat av samarbetet. Där skrev en jurist och en språkvårdare tillsammans alla texter i e-tjänsten, inklusive ledtexter, knapptexter, hjälptexter och felmeddelanden. Samtidigt försäkrade de sig om kvaliteten: "På så sätt blev texterna i tjänsten både begripliga och rättssäkra på samma gång." De stämde kontinuerligt av texterna med den konsult som jobbade med användarvänligheten i e-tjänsten. "Tack vare det lyckade samarbetet mellan språkvård, användbarhet och juridik har vi ett enkelt, begripligt och rättssäkert språk."

Även Socialstyrelsen beskriver att de genom samarbetet kunde arbeta effektivare, eftersom de kunde lösa frågor och problem vartefter de uppstod - antingen direkt i arbetsgruppen eller med hjälp av olika experter. Eftersom gruppen bestod av personer från flera avdelningar, kunde de med hjälp av sina olika kontaktnät snabbt få klargöranden (Plain language in e-services 2016). Därmed kunde de bättre utnyttja kunskaper inom organisationen eller hos externa experter, till exempel konsulter och utbildare. Socialstyrelsen betonar i sin nominering också chefernas betydelse, särskilt att cheferna prioriterade projektet genom att se till att avsätta tid och kompetens och att själva vara tillgängliga för att exempelvis kunna fatta beslut.

På Socialstyrelsen valde man att gemensamt skriva alla texter i så kallade skrivstugor. Arbetsgruppen bestod av två handläggare och två kommunikatörer, varav en språkkonsult. Gruppen träffades flera gånger i veckan, två timmar åt gången, och arbetade gemensamt fram texterna. Arbetssättet visade sig vara mycket effektivt, och det gick snabbare och snabbare eftersom många textavsnitt kunde återanvändas. Under arbetet lärde sig deltagarna dessutom mycket av varandra (Plain language in e-services 2016).

I Sundsvalls kommun hade projektledarna och it-utvecklarna ett nära samarbete med både handläggarna av skolskjutsärenden och andra personer från verksamheten. De samarbetade även externt i sitt kommunnätverk, som gemensamt utvecklar e-tjänster, och delade på så sätt på kompetenser och resurser.

\section{Viktigt att ha med språkvårdare eller kommunikatörer i projektet}

Alla tre myndigheterna beskriver i sina nomineringar hur de kopplade in språkvårdare eller kommunikatörer med klarspråkskompetens i projektet, gärna på ett tidigt stadium av processen, för att försäkra sig om att e-tjänsten skulle vara enkel att förstå och använda. Och det handlade inte bara om den språkliga utformningen utan också i stor 
utsträckning om informationsurval. Bolagsverket formulerar det så här: "Språkvården kom in i arbetet från början och kunde på så sätt vara med och påverka var det skulle finnas texter, var det inte behövde finnas texter och hur texterna skulle formuleras." Även Socialstyrelsen framhåller detta i sin nominering: "Vi utgick helt från målgruppen och vad de sökande behöver veta i varje steg i ansökningsprocessen, och tog bort den information som inte var relevant."

Informationsurvalet påverkade också valet mellan att skriva texter och andra sätt att instruera eller vägleda, vilket beskrivs så här av Sundsvalls kommun: "Vi undvek långa instruktionstexter och försökte istället [låta] gränssnittet och processflödet leda användaren rätt."

I Sundsvalls kommun granskade en kommunikatör med klarspråkskompetens texterna ur aspekter som mottagaranpassning, disposition, rubriker, meningsbyggnad, ord samt ton och tilltal. "Eftersom vi inte vet något annat om användarna än att de är föräldrar har vi försökt vara tydliga och utgått från att användarna är ovana. Vi undviker till exempel uttryck som 'anvisad plats' eftersom vi anser att det är ett abstrakt uttryck och kan vara svårt att ta till sig. Vi vill använda konkreta ord och undvika fackord och byråkratiska uttryck."

\section{Arbetsprocessen - en ständig utvärdering och revidering}

Själva arbetsprocessen skiljer sig åt en del mellan de tre myndigheterna. Det som visar sig vara gemensamt är insikten att man kontinuerligt måste arbeta med att kartlägga och analysera användarnas behov, sätta tydliga mål, utveckla, utvärdera, testa och revidera. Men arbetet är inte slut bara för att e-tjänsten har lanserats. Det är ju då som e-tjänsten testas i verkligheten, och nya problem kan visa sig.

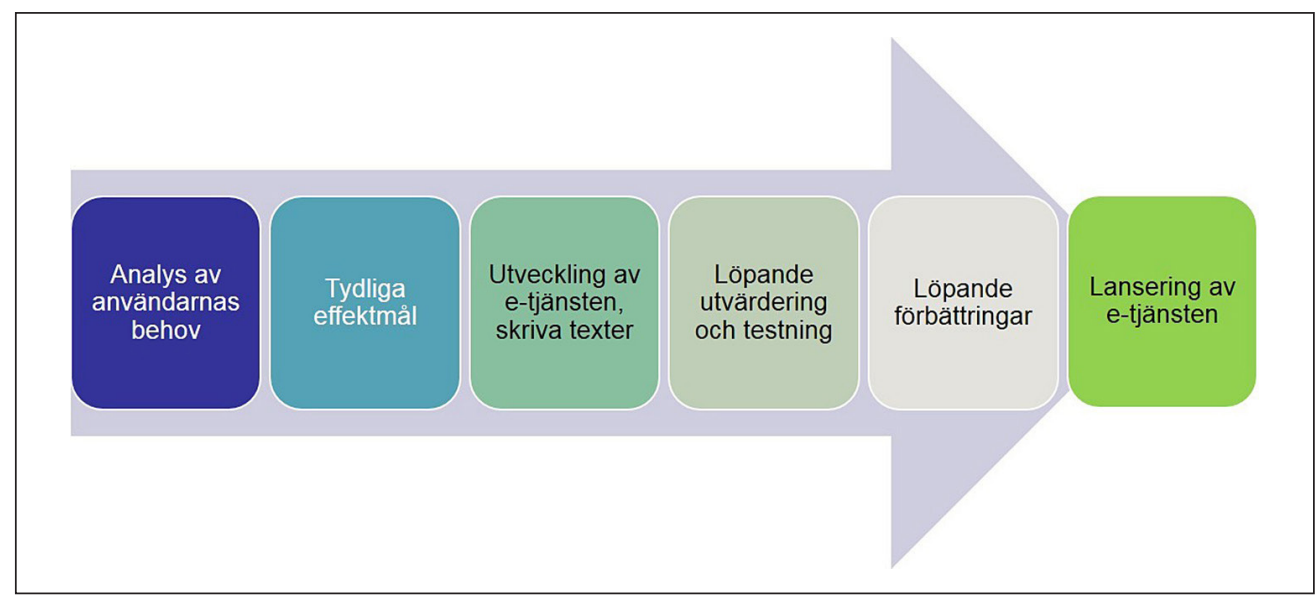

Figur 1: Stegen i arbetsprocessen. I verkligheten är de inte strikt kronologiska utan pågår parallellt och upprepas löpande 
Bolagsverket gjorde användningstester på ett antal lösningsförslag, till exempel för olika navigeringssätt och felmeddelanden. Socialstyrelsen beskriver hur de gjorde användartester för att ta reda på om språket var begripligt. Testningen kan ibland resultera i att man måste göra stora revideringar. I Sundsvalls kommun fick webbyrån helt göra om gränssnittet, eftersom användarna som de testade e-tjänsten på inte förstod hur den skulle användas.

Det behövs också en plan för förvaltning av e-tjänsten och uppföljning av projektet. Bolagsverket beskriver i sin nominering hur de arbetar: "Utifrån utvärderingar, interna och externa synpunkter utvecklar, förbättrar och förvaltar vi ständigt tjänsten. Alla ändringar och all nyutveckling som påverkar tjänsten går via en språkvårdare. Det finns tid avsatt varje vecka för den språkvårdaren att arbeta med förvaltningen av tjänsten. I förvaltningsarbetet ingår också användbarhetsarkitekt, jurist och kravställare."

\section{Språklig kvalitetssäkring och enhetlig terminologi}

Myndigheterna beskriver i sina nomineringar hur de arbetade för att uppnå ett enkelt och enhetligt språk och en konsekvent terminologi. Bolagsverket hade en textgrupp som gemensamt skrev och kvalitetssäkrade texterna (se avsnittet "Samarbete mellan olika kompetenser leder till ökad effektivitet och högre kvalitet"). En fördel var att de arbetade $\mathrm{i}$ en testmiljö där de såg alla texter i sitt rätta sammanhang och lätt kunde ändra om något inte blev begripligt. I deras användningstester ingick frågor om språket i e-tjänsten. Det kom även spontana reaktioner på språket under testerna. I intervjun efteråt ställdes frågan "Finns det begrepp eller termer i tjänsten som du inte förstår?", och svaren bidrog till att språket kunde förbättras.

På Socialstyrelsen skrev man redan från början alla texter med vetskapen om att de senare skulle översättas till andra språk, i första skedet till engelska och arabiska. De beskriver det så här i sin nominering: "Vi försökte använda så vardagsnära ord som möjligt - både för att översättningarna skulle hålla hög kvalitet och för att andraspråkstalare lättare skulle kunna förstå. Alla texter i e-tjänsten riktar sig direkt till målgruppen. Vi tilltalar besökaren med du och talar om Socialstyrelsen som vi." De upprättade också ordlistor och skrev upp ord och uttryck som skulle vara desamma i alla texter, innan de skickade texterna för översättning. Sedan tog de hälp av flerspråkiga kollegor och kontaktpersoner i målgruppen som kvalitetssäkrade översättningarna.

Så här skriver Sundsvalls kommun i sin nominering: "Vi har jobbat hårt med att hålla ett konsekvent och enkelt språk genom hela tjänsten. De termer som används definieras tidigt och ändras inte. Det används minimalt med synonymer, och språket är kortfattat och sakligt." Sundsvalls kommun använde ett direkt tilltal med $d u$ för att rikta texten till den enskilda föräldern och beskriver också hur de försökt undvika intern jargong. När de testade e-tjänsten på de egna handläggarna inför lanseringen, fick 
de synpunkter på att språket var inkonsekvent och att vissa termer inte definierades. Detta kunde därefter rättas till.

\section{Förbättringar av e-tjänsterna och resultat av projekten}

Myndigheterna beskriver i sina nomineringar vilka förbättringar av e-tjänsterna som projekten har lett till, antingen redan under projekten eller efter dem.

Bolagsverket insåg under användningstesterna att många kunder tyckte att det var svårt att registrera aktiebolag. Samtidigt kunde de i sina register se att 65 procent av alla kunder gör samma val när de startar sitt företag. Utifrån detta skapades en förenklad registrering för dem som startar aktiebolag. I denna så kallade enkla anmälan var hälften av alla val som kunden måste göra, till exempel om aktiekapital och revisor, redan gjorda och många uppgifter redan ifyllda. Möjligheten att göra en detaljerad anmälan och själv fylla i allting finns dock fortfarande kvar.

Efter lanseringen av den nya e-tjänsten har Bolagsverket arbetat vidare med andra former att informera nya företagare om hur det går till att registrera företag. De erbjuder checklistor och korta instruktionsfilmer och har även testat en chattfunktion. I chatten kunde handläggaren se samma skärmbild som användaren och även se vilka uppgifter hen har fyllt i, vilket är till stor hjälp. (Bolagsverket muntliga uppgifter 2016)

Socialstyrelsen gick vidare efter pilotprojektet, som omfattade sökande med utbildning i länder utanför Europeiska unionen och EES-området, och fortsatte med övriga länder utifrån samma arbetsmetod och projektmodell. Den tekniska plattform som användes har senare använts för andra delar av webbplatsen. (Socialstyrelsen muntliga uppgifter 2016).

\section{Resultat - uppfylldes effektmålen?}

Sedan Bolagsverket lanserade den nya e-tjänsten för att registrera företag hösten 2014 har telefonsamtalen till deras kundtjänst minskat, liksom antalet synpunkter på e-tjänsten. Myndigheten skriver vidare i sin nominering: "Det stora flertalet kunder reagerar främst på att tjänsten nu upplevs som modern och lättare att förstå." Användningen av e-tjänsterna för att registrera företag har ökat enligt tabell 1:

\begin{tabular}{|l|c|c|c|}
\cline { 2 - 4 } \multicolumn{1}{c|}{} & År & År & År \\
\hline Typ av företag & $\mathbf{2 0 1 2}$ & $\mathbf{2 0 1 5}$ & $\mathbf{2 0 1 6}$ \\
\hline Aktiebolag & $44,7 \%$ & $60,1 \%$ & $66,8 \%$ \\
\hline Enskild firma & $64,4 \%$ & $78,5 \%$ & $84,8 \%$ \\
\hline
\end{tabular}

Tabell 1: Andel nyregistrerade företag i procent som använt e-tjänsten Registrera företag hos Bolagsverket åren 2012, 2015 och 2016 (Nominering till Klarspråkskristallen 2016 Bolagsverket 2016, Bolagsverket 2017) 
Socialstyrelsen skriver i sin nominering att de nya texterna blev kortare, informationen blev mer renodlad och språket enklare. Efter lanseringen ser de av webbstatistiken att besökarna har ett mer logiskt beteende på den nya webbplatsen och inte förflyttar sig så mycket fram och tillbaka mellan olika yrken och olika nivåer i strukturen. Avvisningsfrekvensen - på engelska "bounce rate", dvs. när besökarna omedelbart lämnar sidan - har minskat från 40 procent till 12 procent på de engelskspråkiga webbsidorna, och från 30 procent till 14 procent på de svenskspråkiga sidorna. Detta tyder på att användarna oftare hamnar rätt än tidigare. (Socialstyrelsen 2016a) Kvaliteten på insända ansökningar vore också ett intressant mått på effekten, men den hade ännu inte utvärderats när jag samlade in material och gjorde intervjun med arbetsgruppen hösten 2016.

Sundsvalls kommun hade vid tiden för nominering ännu inte lanserat sin e-tjänst, men fått positiv återkoppling från handläggarna av skolskjutsärenden som tyckte att den såg bra ut, "hanteringen verkar vara enkel och okomplicerad". De var också förvånade över att blanketten kunde bli så enkel i form av en e-tjänst.

\section{Tio framgångsfaktorer}

Med utgångspunkt $\mathrm{i}$ de tre myndigheternas beskrivningar av hur de arbetat i sina utvecklingsprojekt och vilka resultat de uppnått, har jag sammanfattat de viktigaste framgångsfaktorerna i tio punkter ${ }^{1}$ :

1. Fokusera på användarna - analysera noggrant deras behov.

2. Utgå från tidigare erfarenheter av och kunskaper om vad användarna tycker är svårt.

3. Sätt tydliga effektmål, till exempel att korta handläggningstiden eller öka användningen av e-tjänsten.

4. Koppla ihop olika kompetenser och låt utvecklare, handläggare, jurister, kommunikatörer och språkvårdare samarbeta - för en effektivare arbets- och skrivprocess.

5. Skala bort allt innehåll som inte är nödvändigt, skriv korta texter.

6. Använd en enhetlig terminologi och undvik synonymer.

7. Använd ett direkt tilltal: skriv $d u$ om användaren och $v i$ om myndigheten.

8. Utforma informativa rubriker och tydliga knappar, pilar och länkar.

9. Ge en tydlig översikt över var i e-tjänsten användaren befinner sig.

10. Utvärdera, testa och förbättra kontinuerligt under projektets gång - och planera för uppföljningar. 


\section{Slutsatser och slutord}

Utifrån erfarenheterna som framkommer i myndigheternas nomineringar har jag dragit slutsatsen att det lönar sig att avsätta ordentligt med tid i inledningen av projektet, då man framför allt undersöker vilka behov användarna av e-tjänsten har. Ett annat viktigt steg är att sätta tydliga effektmål för projektet. Vad är det som ska uppnås? Kan vissa av målen göras mätbara?

Även sammansättningen av arbetsgruppen och projektorganisationen har stor betydelse och bör föregås av en noggrann analys. Var i organisationen finns viktiga erfarenheter och kunskaper om de uppgifter som e-tjänsten ska utföra? Vilka kompetenser behöver finnas med i projektet? Behöver projektmedlemmarna utbildas? Vilka externa kompetenser behöver man komplettera med? Hur kan cheferna engageras så att projektet får tillgång till de resurser som krävs?

En annan slutsats jag dragit utifrån de här tre exemplen, där man på ett medvetet sätt låtit olika yrken och kompetenser samarbeta, är att projekten inte bara lett fram till att man utvecklat nya e-tjänster - man har samtidigt utvecklat nya arbetsmetoder och rutiner som går att återanvända. Så här beskriver Sundsvalls kommun det: "Arbetsmetoden för framtagande av e-tjänsten går att använda igen, och kommer att användas igen. Det är ett av projektets mål."

Socialstyrelsen skriver i sin nominering att "samarbetet mellan kommunikatörer och handläggare blivit mycket bättre av att sitta tillsammans och arbeta. De förstår varandra bättre och bygger relationer som är till nytta även i andra projekt. Vi har också märkt att nyttan av klarspråk sprider sig till nya yrkesgrupper och nya sammanhang, och hoppas kunna använda det här arbetssättet i många andra projekt på myndigheten."

Med andra ord uppger de att också medarbetarna och organisationen har utvecklats under projekten. Fokus på klarspråk kan alltså ha en positiv effekt på verksamheten i stort och även bidra till lärandet på myndigheten.

\section{Källor}

Ansök om legitimation (2016). Socialstyrelsens webbsidor för att ansöka om legitimation:

http://legitimation.socialstyrelsen.se (hämtad 2016-10-01).

Ansökan om skolskjuts (2016). Sundsvalls kommuns e-tjänst Skolskjuts:

https://sundsvalltest.e-tjansteportalen.se/skolskjuts (hämtad 2016-09-26).

Bolagsverket (2017). E-brev med statistik för år 2016, 2017-08-23.

Nominering till Klarspråkskristallen 2016 (2016). Nominering från Bolagsverket insänd till Språkrådet 2016-02-08, diarienummer 62-16/0177. 
Nominering till Klarspråkskristallen 2016 (2016). Nominering från Socialstyrelsen insänd till Språkrådet 2016-02-08, diarienummer 62-16/0177.

Nominering till Klarspråkskristallen 2016 (2016). Nominering från Sundsvalls kommun insänd till Språkrådet 2016-02-08, diarienummer 62-16/0177.

Persona (user experience) (2016). Wikipedia https://en.wikipedia.org/wiki/Persona_(user_experience) (hämtad 2016-10-26).

Plain language in e-services (2016). Institutet för språk och folkminnen. Filmad intervju av artikelförfattaren med Socialstyrelsens arbetsgrupp 2016-09-30: https://youtu.be/pPEa8XyYzEM (hämtad 2017-05-04).

Registrera företag och skydda företagsnamn (2017). Bolagsverkets webbsidor på verksamt.se om att registrera företag: https://www.verksamt.se/registrera-foretag_info (hämtad 2017-05-04).

Socialstyrelsen (2016a). E-brev om användarbeteenden och webbstatistik 2016-09-27.

Socialstyrelsen (2016b). E-brev om personor 2016-10-31.

Åström, Anna-Karin (2016). E-tjänsten ”Skolskjuts" tog priset. Klarspråk (2), 1.

Dessutom har artikelförfattaren fått vissa muntliga uppgifter från Bolagsverket, Socialstyrelsen och Sundsvalls kommun hösten 2016 samt våren 2017 inför två föredrag.

\section{Summary}

Each year the Language Council of Sweden awards a prize, the Plain Swedish Crystal, to a public authority or a local municipality for its plain language efforts. Each year's Crystal has a different theme. In 2016, the theme was "plain language in e-services". Of course, an e-service must be well-functioning technically, but it is also important that the instructions are comprehensible to the user and that the tone is friendly. Looking through processes behind three services nominated for last year's Crystal, I found several key factors that were common to them all, for example:

- Focus on the users - analyse their needs carefully

- Knowledge from earlier experiences about what users find difficult

- Close cooperation between developers, experts, lawyers, and language advisers

- Consistent and plain terminology

- Continuous evaluation and improvements. 


\section{Bibliografiske oplysninger}

Sandström, Gabriella (2018). Kristallklara e-tjänster - arbetet bakom kulisserna. I: Anne Kjærgaard \& Johanne Lauridsen (red.), Sprog og kommunikation i digital borgerbetjening: Rapport fra Nordisk klarsprogskonference på Schæffergården, 4.-5. maj 2017, (s. 49-63).

DOI: http://dx.doi.org/10.7146/ksn.voio.104234.

https://tidsskrift.dk/ksn/index

(C) Forfatterne og Netværket for sprognævnene i Norden 